\title{
KEDUDUKAN DPRD DALAM PEMBENTUKAN, PENGGABUNGAN, PELEBURAN, DAN PEMBUBARAN BUMD
}

\author{
POSITION OF REGIONAL HOUSE OF PARLIAMENTARY IN THE \\ ESTABLISHMENT, INCORPORATION, MERGER AND LIQUIDA- \\ TION OF LOCAL GOVERNMENT OWNED COMPANY
}

\section{Lalu Wira Pria S.}

Universitas Mataram

Email :wip.intan@gmail.com

\begin{abstract}
Abstact
This study aims to examine and analyze the position of Regional House of Representatives (DPRD) in the formation, merger, fusion, and dissolution of BUMD. This study uses normative legal research methods with statute, conceptual and case study approaches. The legal material in this research is in the form of primary and secondary legal materials, by means of identification, inventory, classification, with deductive analysis techniques. The results of this study indicate that Regional House of Representatives (DPRD) intervention in regional-owned enterprise (BUMD) has consequences for lawlessness, but this authority has legality and obtains legitimacy in the context of checks and balances. To overcome this, it requires the involvement of other parties who have integrity and professionalism.
\end{abstract}

Keywords: Authority; Regional House of Representatives; Regional-Owned Enterprise.

\begin{abstract}
Abstrak
Penelitian ini bertujuan untuk mengkaji dan menganalisis kedudukan DPRD dalam pembentukan, penggabungan, peleburan, dan pembubaran BUMD. Penelitian ini menggunakan metode penelitian hukum normatif dengan pendekatan statute, conceptual dan case study. Bahan hukum dalam penelitian ini berupa bahan hukum primer dan bahan hukum sekunder, dengan caraidentifikasi, inventrisasi, klasifikasi, dengan teknik analisis yang bersifat deduktif. Hasil dari penelitian ini menunjukkan bahwa intervensi DPRD pada BUMD berkonsekuensi pada pelanggaran hukum, tapi kewenangan tersebut memiliki legalitas dan memperoleh legitimasi dalam konteks checks and balances, utk mengatasi hal itu diperlukan keterlibatan pihak lain yang memiliki integritas dan profesionalitas.
\end{abstract}

Kata kunci : Kewenangan; DPRD; BUMD.

\section{PENDAHULUAN}

Kewenagan Dewan Perwakilan Rakyat (DPR) dalam pengisian jabatan negara sering menimbulkan permasalahan hukum, karena pendekatan yang digunakan dalam menggunakan kewenangan tersebut lebih besar dilatarbelakangi oleh kepentingan politik bukan kompetensi atau kapasitas yang dimiliki oleh orang yang akan menduduki jabatan. 
Hal demikian selalu terjadi karena luasnya kewenangan yang diberikan pada lembaga legislatif dalam pengisian jabatan negara maupun institusi yang terkait dengan pemerintahan, mulai dari memberikan persetujuan, memberikan pertimbangan,memilih,dan menyetujui pejabat negara. Kewenanganitu dapat dilihat dalam pasal Undang-Undang Dasar Negara Republik Indonesia (UUD NRI) Tahun 1945 Setelah Perubahan, seperti Pasal 13 ayat $(2)^{1}$ yaitu kewenangan memberikan pertimbangan dalam pengangkatan duta dan konsul, Pasal 23F ayat $(1)^{2}$ kewenangan dalam memilih anggota Badan Pemeriksa Keuangan, Pasal 24A ayat (3) ${ }^{3}$ kewenangan memberikan persetujuan dalam pengangkatan Hakim Agung,Pasal 24B ayat (3) ${ }^{4}$ kewenangan dalam memberikan persetujuan Anggota Komisi Yudisial,danPasal 24C Ayat (3) ${ }^{5}$ kewenangan mengajukan tiga orang dari sembilan Hakim Konstitusi di Mahkamah Konstitusi.

Kewenangan yang diberikan kepada DPR tidak saja diatur dalam UUD NRI, tetapi juga banyak terdapat dalam peraturan peruundang-undangan lainnya, seperti dalam pengangkatan Panglima Tentara Nasional Indonesia (Panglima TNI) ${ }^{6}$, Kepala Kepolisian Republik Indonesia (Kapolri) ${ }^{7}$, Gubernur Bank Indonesia (Gubernur BI) ${ }^{8}, \mathrm{PU}^{9}$, Anggota Komisi Nasional Hak Asasi Manusia (Komnas HAM) ${ }^{10}$, Anggota Komisi Pemberantasan Korupsi (KPK) ${ }^{11}$, Otorititas Jasa Keuangan (OJK) ${ }^{12}$ dan lain-lain.

Kewenangan pengisian pejabat negara oleh DPR sering kali didominasi oleh kepentingan politik dan mengabaikan pertimbangan kapasitas, kapabilitas, transparansi dan

${ }^{1}$ UUD NRI Tahun 1945, Pasal 13 ayat (2) "Dalam hal mengangkat duta, Presiden memperhatikan pertimbangan Dewan Perwakila Rakyat".

${ }^{2}$ UUD NRI Tahun 1945, Pasal 23F ayat (1) "Anggota Badan Pemeriksa Keuangan dipilih oleh Dewan Perwakilan Rakyat dengan memperhatikan pertimbangan Dewan Pertimbangan Daerah dan diresmikan oleh Presiden".

${ }^{3}$ UUD NRI Tahun 1945, 24A ayat (3) "Calon hakim agung diusulkan Komisi Yudisial kepada Dewan Perwakilan Rakyat untuk mendapatkan persetujuan dan selanjutnya ditetapkan sebagai hakim agung oleh presiden"

${ }^{4}$ UUD NRI Tahun 1945, Pasal 24B ayat (3) "Anggota Komisi Yudisial diangkat dan diberhentikan oleh Presiden dengan persetujuan Dewan Perwakilan Rakyat".

${ }^{5}$ UUD NRI Tahun 1945, Pasal 24C ayat (3) "Mahkamah Konstitusi mempunyai sembilan orang anggota hakim konstitusi yang ditetapkan oleh Presiden, yang diajukan masing-masing tiga orang oleh Mahkamah Agung, tiga orang oleh Dewan Perwakilan Rakyat, dan tiga orang oleh Presiden".

${ }^{6}$ UU Nomor 34 Tahun 2004 Tentang Tentara Nasional Indonesia, Pasal 13 ayat (2) Panglima sebagaimana dimaksud pada ayat (1) diangkat dan diberhentikan oleh Presiden setelah mendapat persetujuan Dewan Perwakilan Rakyat. (LNRI Tahun 2004 Nomor 127, TLNRINomor 4439).

${ }^{7}$ UU Nomor 2 Tahun 2002 Tentang Kepolisian Negara Republik Indonesia,Pasal 11 ayat (1)

Kapolri diangkat dan diberhentikan oleh Presiden dengan persetujuan Dewan Perwakilan Rakyat. (LNRI Tahun 2002Nomor 2, TLNRI No 4168).

${ }^{8}$ UU Nomor23 Tahun 1999 Tentang Bank Indonesia, Pasal 41 ayat (1) Gubernur dan Deputi Gubernur Senior diusulkan dan diangkat oleh Presiden dengan Dewan Perwakilan Rakyat. (LNRI Tahun 1999Nomor 66, TLNRI No 3843).

${ }^{9}$ UUNomor 7 Tahun 2017 Tentang Pemilihan Umum Pasal 25 ayat (2) DPR memilih calon anggota KPU berdasarkan hasil uji kelayakan dan kepatutan, ayat (3) DPR menetapkan 7 (tujuh) nama calon anggota KPU berdasarkan urutan peringkat teratas dari 14 (empat belas) nama calon sebagaimana dimaksud dalam Pasal 24 ayat (1) berdasarkan hasil uji kelayakan dan kepatutan sebagaimana dimaksud pada ayat (2), sebagai calon anggota KPU terpilih. (LNRI Tahun 2017Nomor 182, TLNRI No 6109).

${ }^{10}$ UU Nomor 39 Tahun 1999 Tentangisp:Hak Asasi Manusia, Pasal 83 ayat (1) Anggota Komnas HAM berjumlah 35 (tiga puluh lima) orang yang dipilih oleh Dewan Perwakilan Rakyat Republik Indonesia berdasarkan usulan Komnas HAM dan diresmikan oleh Presiden selaku Kepala Negara. (LNRI Tahun 1999Nomor 165, TLNRI No 3886).

${ }^{11}$ UU Nomor 30 Tahun 2002 Tentang Komisi Pemberantasan Tindak Pidana Korupsi, Pasal 30 ayat (1) Pimpinan Komisi Pemberantasan Korupsi sebagaimana dimaksud dalam Pasal 21 ayat (1) huruf a dipilih oleh Dewan Perwakilan Rakyat Republik Indonesia berdasarkan calon anggota yang diusulkan oleh Presiden Republik Indonesia. (LNRI Tahun 2002Nomor 137, TLNRI No 4250).

${ }^{12}$ UU Nomor 21 Tahun 2011 Tentang Otoritas Jasa Keuangan Pasal 11 ayat (1) Anggota Dewan Komisioner sebagaimana dimaksud dalam Pasal 10 ayat (4) huruf a sampai dengan huruf g dipilih oleh Dewan Perwakilan Rakyat berdasarkan calon anggota yang diusulkan oleh Presiden. (LNRI Tahun 2011Nomor 111, TLNRI No 5253). 
akuntabilitas. Fraksi-fraksi di DPR sering kali tidak memberikan alasan pertimbangan yang rasional ketika menentukan pilihan pejabat negara tersebut. Bahkan sering terjadi korupsi dalam prosespemilihan pejabat negara seperti yang terjadi dalam kasus Traveller Cheques yang melibatkan beberapa oknum Anggota DPR dalam pemilihan Deputi Senior Gubernur Bank Indonesia pada tahun 2004 (Putusan Kasasi Mahkamah Agung Nomor 545 K/Pid.Sus/2013).Mantan Ketua Mahkamah Konstitusi, Mahfud MD, mengatakan ${ }^{13}$ :

"Peran DPR untuk menentukan pejabat publik melalui fit and proper test telah meningkatkan skala korupsi dan penyuapan-penyuapan yang sangat menjijikkan di Indonesia. Seperti diketahui, saat ini untuk menjadi pejabat-pejabat negara seperti hakim agung, hakim konstitusi, anggota BPK, komisioner KPU, komisioner Komisi Yudisial, gubernur Bank Indonesia, deputi gubernur Bank Indonesia, penentuan duta besar, dan lain-lain harus dilakukan melalui persetujuan atau pertimbangan dari DPR. Sebenarnya pemberian wewenang kepada DPR untuk ikut menentukan pejabat-pejabat publik dilatarbelakangi oleh upaya pembalikan terhadap sistem yang dilakukan oleh Orde Baru di bawah Presiden Soeharto".

Kewenangan DPR dalam pengisian pejabat negara tersebut sering menjadi permasalahan secara hukum, dan keinginan untuk terlibat tersebut juga terjadi pada badan usaha yang dibentuk oleh negara yaitu Badan Usaha Milik Negara (BUMN). Keinginan DPR terlibat dalam pemilihan pimpinan pada BUMN adalah suatu yang telah keluar dari fungsi DPR karena tidak terkait dengan fungsi yang telah ditentukan. Keinginan untuk terlibat ini juga terlihat di daerah yaitu dengan keterlibatan DPRD pada Badan Usaha Milik Daerah (BUMD), dan seperti permasalahan yang terjadi pada penentuan pejabat oleh DPR, permasalahan itu juga terjadi pada keterlibatan DPRD dalam pengaturan BUMD.

Berkaitan dengan permasalahan keterlibatan DPRD pada BUMD ini akan menjadi kajian penulis dengan pendekatan statuta approach, conseptual approach, dan case approach. Kajian ini berkaitan dengan kedudukan DPRD dalam pembentukan, pengggabungan, peleburan, dan pembubaranBUMD.

\section{PEMBAHASAN}

\section{Kedudukan DPR pada BUMN}

Mahkamah Konstitusi (MK) menilai tidak ada relevansinya melibatkan DPR dalam aksi atau tindakan korporasi yang dilakukan oleh BUMN Persero sebab DPR bukanlah bagian dari RUPS maupun Dewan Komisaris. Pengawasan DPR harus diletakkan dalam kerangka fungsi pengawasan politik terhadap pelaksanaan pemerintahan yang dilakukan oleh Presiden sebagai pemegang kekuasaan pemerintahan menurut Pasal 4 UUD 1945. Misalnya ketika Presiden mengajukan rancangan undang-undang tentang

\footnotetext{
${ }^{13}$ http://nasional.sindonews.com/berita/788395/dpr-memang-kebablasan, diakses Rabu, 19 Agustus 2020
} 
APBN. Pada saat itulah DPR mempertanyakan pengelolaan keuangan negara dalam pelaksanaan pemerintahan, termasuk yang telah Pemerintah alokasikan untuk BUMN.

Dalam pelaksanaan pemerintahan yang baik fungsi Pengawasan dapat di golongkan menjadi tiga bagian yaitu: (1) pengawasan menurut sifat yaitu menurut sifat preventif yang dilakukan sebelum suatu kegiatan dilakukan (tindakan jaga-jaga) dan sifat represif di mana merupakan pengawasan yang dilakukan setelah suatu kegiatan di laksanakan; (2) pengawasan menurut objek yaitu pengawasan yang dilakukan terhadap subjek/pemerintah yang tak lain adalah merupakan pelaksana tugas pemrintahan serta pengawasan terhadap produk hukum dan sarana yang di gunakan. (3). pengawasan menurut pelaku yaitu pengawasan yang dilakukan melalui lembaga Negara MPR,DPR, dan social control/pengawasan langsung taupun tidak langsung dari masyarakat, serta pengawasan internal, pengawasan lewat lembaga peradilan, pengawasan melalui lembaga ombusmen dan pengawasan melalui lembaga independen. ${ }^{14}$

Untuk melihat sejauh mana fungsi pengawasan DPR terhadap BUMN, MK membedakan antara tindakan memberikan modal untuk mendirikan BUMN atau menambah modal BUMN dengan tindakan BUMN itu sendiri. Tindakan memberikan modal untuk mendirikan BUMN atau menambah modal BUMN memerlukan keterlibatan DPR sebab modal BUMN berasal dari kekayaan negara yang dipisahkan, yaitu kekayaan negara yang berasal dari APBN.

BUMN merupakan badan hukum dengan modal berupa kekayaan yang dipisahkan dari kekayaan negara. Di dalam praktik saat ini menjadi permasalahan terkait dengan kedudukan Persero sebagai badan usaha yang berbentuk BUMN yang di dalamnya terdapat kekayaan negara. Dengan adanya kekayaan negara yang dipisahkan ke dalam Persero tidak lantas menjadikan Persero tetap berada dalam rezim hukum publik. Dalam praktik terdapat 2 penafsiran masing-masing mengklaim berada dalam rezimnya. Penganut rezim hukum publik menganggap dalam kondisi seperti itu BUMN yang berbentuk Persero tetap tunduk pada rezim hukum publik, sebaliknya para akademisi memandang sesuai dengan argumentasinya, bahwa BUMN yang berbentuk Persero harus tunduk pada rezim hukum privat. $^{15}$

Dengan adanya perbedaan pandangan mengenai kedudukan BUMN Persero tersebut, mengakibatkan kurang optimalnya peran BUMN Persero dalam menjalankan aktivitas bisnisnya. Dalam kasus pengambilan kebijakan Direksi BUMN yang pure business dan nyatanya berdampak pada kerugian BUMN serta implikasinya terhadap berlakunya ketentuan Undang-Undang Tindak Pidana Korupsi memang telah ada contoh kasus riil-nya. Menurut Bagian Hukum Kementerian BUMN, BUMN yang bergerak di bidang

\footnotetext{
${ }^{14}$ Sunardi, Fungsi Pengawasan DPR terhadap Pemerintah dalam Mewujudkan Good Governance dan Clean Government ditinjau dari Perspektif Politik Hukum, Jurnal Meta Yuridis Volume 1 No.2 Tahun 2018, hal. 26-27

${ }^{15}$ Ikhwansyah, I., Chandrawulan, A. A., \& Amalia, P. (2018). Optimalisasi Peran Badan Usaha Milik Negara (BUMN) pada Era Masyarakat Ekonomi Asean (MEA). Jurnal Media Hukum, 25(2), 150-161.
} 
perkebunan karet dan sawit di Lampung, direksinya ditetapkan telah merugikan keuangan negara yang melanggar Undang-Undang Tindak Pidana Korupsi. Padahal, pengambilan kebijakan yang dilakukan direksi adalah pure business yang dilandasi profesionalisme. Kerugian muncul karena dipengaruhi oleh faktor eksternal yaitu kondisi harga karet dan sawit ketika itu yang secara dramatis melambung tinggi. Oleh karena itu, hukum harus segera memberikan kepastian terhadap kedudukan BUMN Persero dalam menjalankan aktivitas bisnisnya, apakah tunduk pada rezim hukum privat atau rezim hukum publik. ${ }^{16}$

Sedangkan setelah BUMN terbentuk, BUMN akan menjadi subjek hukum berupa badan hukum (rechtspersoon atau legal person). Sebagai subjek hukum, BUMN adalah pemegang hak dan kewajiban menurut hukum dan berhak melakukan perbuatan hukum. Dalam melakukan perbuatan hukum BUMN diwakili oleh Direksi, sebagaimana ditentukan dalam Pasal 5 UU BUMN. Perbuatan hukum BUMN dapat berupa perbuatan hukum pada umumnya maupun perbuatan hukum dalam rangka aksi atau tindakan korporasi. Penggabungan BUMN menurut MK merupakan bagian dari tindakan atau aksi korporasi yang artinya tindakan itu baru ada setelah BUMN dibentuk atau pengurusan perseroan. Menurut Pasal 31 UU BUMN jo Pasal 108 ayat (1) UU 40/2007, pengawasannya dilakukan oleh Komisaris. ${ }^{17}$

Sebelum amandemen UUD NRI Tahun 1945, tidak ditemukan satu pasalpun yang mengatur kekuasaan DPR RI dalam pengisian pejabat negara. Hal ini disebabkan karena desain ketatanegaraan menurut UUD NRI Tahun 1945 sebelum perubahan menempatkan kekuasaan legislatif yang lemah dibandingkan kekuasaan eksekutif. Desain yang ada dalam UUD NRI Tahun 1945 sebelum perubahan menempatkan posisi eksekutif pada posisi yang sangat kuat (executive heavy). Kemudian setelah terjadi amandemen UUD NRI Tahun 1945 maka kekuasaan didominasi lembaga legislatif berubah dan menjadi lebih kuat daripada eksekutif (legislative heavy).

Kewenangan yang besar bagi DPR dalam menentukan pejabat negara juga merambah pada BUMN, padahal kewenangan DPR terhadap lembaga ini tidak relevan karena institusi ini adalah lembaga yang secara hukum adalah badan hukum yang memiliki otoritas sendiri dalam menentukan segala kebijakan yang terkait dengan kelangsungan dari lembaga.

Keinginan Dewan Perwakilan Rakyat (DPR) melakukan uji kelayakan dan kepatutan calon direksi badan usaha milik negara (BUMN) merupakan bentuk campur tangan terlampau jauh lembaga legislatif terhadap perusahaan pelat merah. DPR memasukkan aturan keterlibatannya memilih direksi BUMN itu dalam rancangan revisi Undang-Un-

\footnotetext{
${ }^{16}$ Ibid.

${ }^{17} \mathrm{https}$ ///www.larasonline.com/berita/MK-Tolak-Permintaan-Pelibatan-DPR-Dalam-Aksi-KorporasiPenggabungan-BUMN, diakses pada tanggal 27 Agustus 2020
} 
dang Badan Usaha Milik Negara. Draft revisi ini akan dibahas Badan Legislasi DPR dalam persidangan pada awal Juli. ${ }^{18}$

Proses uji kelayakan dan kepatutan yang dilaksanakan di DPR jelas akan membuat proses tersebut menjadi transaksisonal dan terjadinya bargaining secara politik. Hal ini sangat jauh dari pertimbangan dipilihnya seorang direksi, sebab direksi dinilai dari kapasitasnya dalam berbisnis dan mengelola lembaga bisnis bukan keuggulannya melakukan lobi politik. Apabila kondisi transaksional itu menjadi bahan pertimbangan dalam memilih direksi BUMN, maka jelas akan menjadikan orang yang dipilih dan lembaga BUMN tersebut menjadi alat kekuasaan politik saja dan terjadinya moral hazard serta pengabaian terhadap hukum.

Padahal Berdasarkan paham Rechtsstaat, pada hakikatnya hukum menjadi penentu segalanya sesuai dengan prinsip nomokrasi (nomokracy) dan doktrin 'the Rule of Law, and not of Man'. Dalam kerangka 'the rule of Law', diyakini adanya pengakuan bahwa hukum itu mempunyai kedudukan tertinggi (supremacy of law), adanya persamaan dalam hukum dan pemerintah (equality before the law), dan berlakunya asas legalitas dalam segala bentuknya dalam kenyataan praktek (due process of law). ${ }^{19}$

Keinginan untuk terlibat dalam proses yang bersifat teknis justru telah membuat lembaga DPR keluar dari fungsi yang telah ditentukan secara konstitusional, karena proses tersebut adalah kegiatan yang berkaitan dengan pelaksanaan, dan akhirnya jika nanti terjadi pelanggaran dalam pelaksanaan, maka tidak dapat lepas dari peran DPR dalam memilih orang-orang yang berada pada lembaga tersebut.

Padahal secara hukum bahwa korporasi yang berbentuk BUMN adalah lembaga yang telah diatur oleh berbagai peraturan, termasuk juga struktur kewenangan yang terdapat pada BUMN, sehingga melibatkan peran lembaga lain atau organ lain jelas akan merusak struktur yang terdapat pada BUMN. Seperti diketahui bahwa kebijakan yang bersifat fundamental pada lembaga yang berbentuk BUMN telah diatur sedemikian rupa, yaitu adanya organ RUPS, dewan komisaris, dan direksi, dan telah diatur kedudukan dan kewenangan masing-masing organ, jadi tidak diperlukan lagi intervensi dari lembaga luar dalam pengelolaan BUMN, apalagi hal itu bersifat politis.

Oleh karena itu, keterlibatan DPR dalam hal proses yang bersifat teknis adalah tindakan dan perbuatan yang tidak relevan bagi kemajuan BUMN, karena sudah keluar dari fungsi pengawasan yang diatur, dan jika DPR ingin terlibat dan melakukan kontrol terhadap proses tersebut dapat dilakukan dengan melibatkan lembaga lain untuk melakukan audit seperti Badan Pemeriksa Keuangan.

\footnotetext{
${ }^{18} \mathrm{https} / /$ kolom.tempo.co/read/1000336/bahaya-dpr-memilih-direksi-bumn, diakses pada tanggal 10 Agustus 2020

${ }^{19}$ Rajab, A. (2018). PERAN PENTING BADAN KEAHLIAN DPR RI DALAM SISTEM HUKUM PEMBENTUKAN PERATURAN PERUNDANG-UNDANGAN YANG MENDUKUNG TERWUJUDNYA KEADILAN UNTUK KEDAMAIAN. Jurnal Legislasi Indonesia, 14(2), 233-243..
} 
Berbagai kritik terhadap isi RUU BUMN pun bermunculan. Pasalnya, isi RUU tersebut memuat kewenangan DPR dalam pengawasan BUMN menjadi lebih superior. Salah satu kewenangan tersebut yaitu penunjukkan direksi dan komisaris harus mendapat persetujuan DPR. Selain itu, DPR berhak menentukan aksi bisnis BUMNseperti privatisasi, merger, spin off (pembentukan entitas baru) dan pembentukan holding. ${ }^{20}$

\section{Kedudukan DPRD pada BUMD}

Keterlibatan legislatif dalam proses pemilihan pejabat pada korporasi juga ada di daerah, yaitu dengan ikut serta dalam menentukan mekanisme yang terkait dengan keputusan dalam hal pembentukan, penggabungan, peleburan, dan pembubaran Badan Usaha Milik Negara (BUMD).

Penggabungan atau sering disebut dengan merger ${ }^{21}$ adalah The fusion or absorption of one thing or right into another, generally spoken of a case where one of the subjects is of less dignity or importance than the another.Pringle dan Harris ${ }^{22}$ mengartikan merger sebagaia combination of two or more firm in which one company survives under its own name while any others cease to exit as legal entities. Menurut Cristian Wibisono, penggabungan perusahaan adalah penggabungan dua badan usaha atau lebih yang relatif berimbang kekuatannya sehingga terjadi kombinasi baru yang merupakan wadah bersama yang saling memperkuat. ${ }^{23}$

Jadi penggabungan adalah suatu kebijakan dari dua atau lebih perusahaan untuk menggabungkan diri menjadi satu perusahaan baru, dalam bisnis penggabungan diartikan sebagai penyatuan beberapa unit ekonomi, proses penggabungan memerlukan proses cukup lama karena masing-masing perusahaan berusaha mensinkronisasikan beberapa aspek seperti permodalan, manajemen, sumber daya manusia maupun dari aspek hukum.

Sedangkan peleburan atau konsolidasiberdasarkan Pasal 1 angka 10 Undang-Undang Nomor 40 Tahun 2007 Tentang Perseroan Terbatas ${ }^{24}$ diartikan sebagai perbuatan hukum yang dilakukan oleh dua perseroan atau lebih untuk meleburkan diri dengan cara mendirikan Perseroan baru yang karena hukum memperoleh aktiva dan pasiva dari perseroan yang meleburkan diri dan status hukumnya perseroan yang meleburkan diri berakhir karena hukum.

\footnotetext{
${ }^{20} \mathrm{https}$ //www.hukumonline.com/berita/baca/1t5c1230587092e/menyoal-superioritas-dpr-dalam-revisi-uu-bumn/ diakses pada tanggal 27 Agustus 2020

${ }^{21}$ Bryan A. Garner (ed.) 1999, Black's Law Dictionary Seventh Edition, (St. Paul Minn : West Publishing Co., hlm. 682

${ }_{22}$ Pringle, J. J. , and Harris, R. S, 1987, Essentials of Managerial Finance, second Illinois-London, hlm. 778

${ }^{23}$ Cristian Wibisono, 1995, Merger dan Akuisisi di Indonesia, Seminar Merger dan Akuisisi, Jakarta, hlm.2

${ }^{24}$ Undang-Undang Nomor 40 Tahun 2007 tentang Perseroan Terbatas (Lembaran Negara Republik Indonesia Tahun 2007 Nomor 106, Tambahan Lembaran Negara Republik Indonesia Nomor 4756)
} 
Undang-Undang Nomor 23 Tahun 2014 tentang Pemerintahan Daerah ${ }^{25}$ menentukan bentuk BUMD terdiri atas Perusahaan Umum Daerah dan Perusahaan Perseroan Daerah.

Perusahaan Umum Daerah adalah BUMD yang seluruh modalnya dimiliki oleh satu daerah dan tidak terbagi atas saham. Dalam hal perusahaan umum daerah akan dimiliki oleh lebih dari satu daerah, perusahaan umum daerah tersebut harus merubah bentuk hukum menjadi perusahaan perseroan daerah. Perusahaan umum Daerah dapat membentuk anak perusahaan dan/atau memiliki saham pada perusahaan lain.

Sedangkan Perusahaan Perseroan Daerah adalah BUMD yang berbentuk perseroan terbatas yang modalnya terbagi dalam saham yang seluruhnya atau paling sedikit $51 \%$ (lima puluh satu persen) sahamnya dimiliki oleh satu daerah. Perusahaan perseroan Daerah setelah ditetapkan dengan peraturan daerah (Perda), pembentukan badan hukumnya dilakukan berdasarkan ketentuan peraturan perundang-undangan mengenai perseroan terbatas. Dalam hal pemegang saham Perusahaan Perseroan Daerah terdiri atas beberapa daerah dan bukan daerah, salah satu daerah merupakan pemegang saham mayoritas.

Pendirian BUMD ditetapkan dengan Perda, untuk perusahaan perseroan daerah setelah ditetapkan dengan Perda, pembentukan badan hukumnya dilakukan berdasarkan ketentuan peraturan perundang-undangan mengenai perseroan terbatas.

Selain pendirian, terkait dengan penggabungan, peleburan, pembubaran BUMD ditetapkan juga dengan Perda yang secara hierarkis merupakan kebijakan tertinggi di daerah, ${ }^{26}$ hal ini berbeda dengan kebijakan yang terkait pendirian BUMN.

Keberadaan BUMD selama ini tidak seperti BUMN yang sebagian besar kegiatan usahanya sudah menerapkan prinsip-prinsip tata kelola perusahaan yang baik atau sesuai dengan prinsip-prinsip good corporate governance yang dituangkan dalam Keputusan Menteri BUMN Nomor Kep- 103/MBU/2002 tentang pembentukan komite audit bagi BUMN. Kondisi BUMN selangkah lebih maju dibandingkan dengan kegiatan usaha yang dilakukan oleh BUMD, dan bahkan perusahaan negara yang berbentuk perseroan

${ }^{25}$ Undang-Undang Nomor 23 Tahun 2014 tentang Pemerintahan Daerah (Lembaran Negara Republik Indonesia Tahun 2014 Nomor 244, Tambahan Lembaran Negara Republik Indonesia Nomor 5587) sebagaimana telah beberapa kali di ubah terakhir dengan Undang-Undang Nomor 9 Tahun 2015 tentang Perubahan Kedua Atas Undang-Undang Nomor 23 Tahun 2014 tentang Pemerintahan Daerah (Lembaran Negara Republik Indonesia Tahun 2015 Nomor 58 , Tambahan Lembaran Negara Republik Indonesia Nomor 5679).

${ }^{26}$ Undang-Undang Nomor 12 Tahun 2011 tentang Pembentukan Peraturan Perundang-Undangan (Lembaran Negara Republik Indonesia Tahun 2011 Nomor 82, Tambahan Lembaran Negara Republik Indonesia Nomor 5234) sebagaimana telah diubah dengan Undang-Undang Nomor 15 Tahun 2019 tentang Perubahan atas Undang-Undang Nomor 12 Tahun 2011 tentang Pembentukan Peraturan Perundang-Undangan (Lembaran Negara Republik Indonesia Tahun 2019 Nomor 183, Tambahan Lembaran Negara Republik Indonesia Nomor 6398); Junctis Peraturan Presiden Nomor 87 Tahun 2014 tentang Peraturan Pelaksanaan Undang-Undang Nomor 12 Tahun 2011 tentang Pembentukan Peraturan Perundang- Undangan (Lembaran Negara Republik Indonesia Tahun 2014 Nomor 199), Peraturan Menteri Dalam Negeri Nomor 80 Tahun 2015 tentang Pembentukan Produk Hukum Daerah (Berita Negara Republik Indonesia Tahun 2015 Nomor 2036) 
sudah melangkah menjadi perusahaan publik dengan menerbitkan sahamnya di lantai bursa. $^{27}$

Friedman mengatakan bahwa keterlibatan negara dalam bidang ekonomi diletakkan pada tiga bentuk perusahaan negara, yaitu: (1) department government enterprise, adalah perusahaan negara yang merupakan bagian integral dari suatu departemen pemerintahan yang kegiatannya bergerak di bidang public utilities; (2) statutory public corporation, adalah perusahaan negara yang sebenarnya hampir sama dengan departement government enterprise, hanya dalam hal manajemen lebih otonom dan bidang usahanya masih tetap public utilities; (3) commercial companies, adalah perusahaan yang merupakan campuran modal swasta dan diberlakukan hukum privat. $^{28}$

Konsep Friedman ini sebetulnya diadopsi oleh pemerintah Indonesia, dalam pengelolaan BUMD. Dalam PP BUMD disebutkan bahwa bentuk hukum BUMD adalah Perusahaan Umum Daerah yang fokus pada sektor public utilities dan BUMD dengan bentuk hukum Perusahaan Persero Daerah yang fokusnya adalah mengejar keuntungan (commersial companies). Jadi, sebenarnya telah ada sebuah road map sederhana mengenai pengelolaan BUMD terkait posisi pemerintah daerah sebagai pelaku usaha. Namun, pengelolaan kebutuhan strategis yang terkait hajat hidup orang banyak memerlukan investasi yang besar, yang tidak bisa ditanggung sendiri oleh kemampuan pemerintah daerah. ${ }^{29}$

Undang-Undang Nomor 19 tahun 2003 tentang Badan Usaha Milik Negara, ${ }^{30}$ bahwa BUMN terdiri dari Perusahaan Perseroan (Persero) dan Perusahaan Umum (Perum). Perusahaan Perseroan, yang selanjutnya disebut Persero, adalah BUMN yang berbentuk perseroan terbatas yang modalnya terbagi dalam saham yang seluruh atau paling sedikit 51 \% (lima puluh satu persen) sahamnya dimiliki oleh Negara Republik Indonesia yang tujuan utamanya mengejar keuntungan.

Perusahaan Umum, yang selanjutnya disebut Perum, adalah BUMN yang seluruh modalnya dimiliki negara dan tidak terbagi atas saham, yang bertujuan untuk kemanfaatan umum berupa penyediaan barang dan/atau jasa yang bermutu tinggi dan sekaligus mengejar keuntungan berdasarkan prinsip pengelolaan perusahaan.

Pendirian Perum diusulkan oleh Menteri kepada Presiden, disertai dengan dasar pertimbangan setelah dikaji bersama dengan Menteri Teknis dan Menteri Keuangan. Perum memperoleh status badan hukum sejak diundangkannya Peraturan Pemerintah tentang pendiriannya.

\footnotetext{
${ }^{27}$ Muryanto, Y. T. (2014). Model Pengelolaan Badan Usaha Milik Daerah (BUMD) Dalam Rangka Mewujudkan Good Corporate Governance. Yustisia Jurnal Hukum, 3(1).

${ }^{28}$ Sri Widiyastuti, Politik Hukum Badan Usaha Milik Daerah (BUMD) dalam Kegiatan Bisnis untuk Mewujudkan Kesejahteraan Sosial , Jurnal Law and Justice, Vol. 4 No. 1 April, 2019, hal. 27

${ }^{29}$ Ibid.

${ }^{30}$ Undang-Undang Nomor 19 tahun 2003 tentang Badan Usaha Milik Negara (Lembaran Negara Republik Indonesia Tahun 2003 Nomor 70, Tambahan Lembaran Negara Republik Indonesia Nomor 4297)
} 
Sedangkan pendirian Persero diusulkan oleh Menteri kepada Presiden disertai dengan dasar pertimbangan setelah dikaji bersama dengan Menteri Teknis dan Menteri Keuangan, dan terhadap Persero berlaku segala ketentuan dan prinsip-prinsip yang berlaku bagi perseroan terbatas.

Kewenangan DPRD terhadap BUMD terdapat dalam peraturan seperti yang diatur dalam Pasal 331 ayat (2) disebutkan bahwa pendirian BUMD ditetapkan dengan Perda. Dari ketentuan ini bahwa keterlibatan DPRDmendapatkan legalitas dalam pembentukan BUMD, hal ini walaupun terlihat ironis namun nyatanya dimuat dalam peraturan, sehingga keterlibatan DPRD mendapat justifikasi melalui peraturan.

Dari kedua pasal ini terlihat bahwa terdapat intervensi DPRD dalam pembentukan BUMD, yaitu melalui pembentukan Perda, dan dalam pembentukan peraturan daerah ini jelas campur tangan DPRD tidak dapat dihindari karena memerlukan pembahasan dan kesepakatan dari DPRD.

Proses penyusunan, pembahasan, persetujuan, dalam pembentukan Perda selalu melibatkan DPRD, sehingga mekanisme transaksional dan bersifat politis tidak dapat dihindari, di sinilah terlihat bahwa DPRD juga terlibat dalam pembentukan kebijakan korporasi yang ada di daerah, sebab kepala daerah bukanlah merupakan penguasa tunggal di daerah, karena penyelenggara pemerintah daerah adalah kepala daerah dan DPRD, hal ini diharapkan agar tercipta iklim demokrasi dalam penyelenggaraan pemerintahan daerah, kemudian terjadi check and balance, gambaran tersebut dapat diklarifikasikan menjadi tiga jenis hubungan, yaitu hubungan kemitraan (partnership), hubungan pengawasan (controlling), dan hubungan anggaran (budgeting), sepertihalnya hubungan antara DPR dengan Presiden pada Pemerintah Pusat. ${ }^{31}$

Selain keterlibatan DPRD dalam pembentukan BUMD, keterlibatan DPRD juga dalam pembubaran perusahaan umum daerah yang ditetapkan dengan Perda seperti yang ditentukan dalam Pasal 338 ayat (2), kemudian keterlibatan terdapat dalam permodalan yang diberikan kepada BUMD, seperti yang diatur dalam pasal 333 ayat (1) yang menyebutkan bahwa modal yang berasal dari penyertaan modal pada BUMD ditetapkan dengan Perda.

Pada prisipnya urgensi jenis hubungan antara legislatif dan ekskutif daerah tersebut meliputi hal-hal yaitu: representasi, anggaran, pertanggungjawaban, pembuatan peraturan daerah, pengangkatan sekeretaris daerah, pembinaan dan pengawasan. ${ }^{32}$

Selain diatur dalam Undang-Undang Nomor 23 Tahun 2014 tentang Pemerintahan Daerah, BUMD juga diatur dalam Peraturan Pemerintah Nomor 54 Tahun 2017Ten-

\footnotetext{
${ }^{31}$ I Gde Panca Astawa, 2008, Problematika Hukum Otonomi Daerah di Indonesia, Alumni, Bandung, hlm. 112

${ }^{2}$ J Kaloh. 2002, Mencari Bentuk Otonomi Daerah Suatu Solusi Dalam Menjawab Kebutuhan Lokal dan Tantangan Global, Rineka Cipta, Jakarta, hlm. 149
} 
tangBadan Usaha Milik Daerah ${ }^{33}$, Peraturan ini merupakan peraturan pelaksana dari Undang-Undang Nomor 23 tahun 2014 yang mengatur tentang kelembagaan dan ketentuan teknis BUMD. Berkaitan dengan keterlibatan DPRD dalam kebijakan yang terkait BUMD dapat dilihat dalam beberapa pasal Peraturan Pemerintah Nomor 54 Tahun 2017 tentangBadan Usaha Milik Daerah, seperti Pasal 124ayat (1) yang menyebutkan bahwa pembubaran BUMD ditetapkan dengan Perda, kemudian dalam Pasal 125 bahwa terhadap ketentuan penggabungan, peleburan, pengambilalihan, dan pembubaran BUMD dilakukan berdasarkan hasil analisis investasi, penilaian tingkat kesehatan, dan hasil evaluasi BUMD.

Dari ketentuan yang diatur dalam Undang-Undang Nomor 23 tahun 2014 tentang Pemerintahan Daerah bahwa campur tangan DPRD terhadap BUMD memiliki dasar hukum, atau memiliki legalitas dalam hukum positif, sehingga tindakan yang berbentuk intervensi yang dilakukan DPRD kepada BUMD mendapatkan legitimasi secara hukum, tapi intervensi tersebut sering menimbulkan permasalahan secara hukum.

Salah satu contoh terkait dengan kebijakan BUMD yang berkosekuensi pada pelanggaran hukum terjadi pada perubahan bentuk PD. BPR NTB ke PT. BPR NTB. Pertama, adalah permasalahan yang berkaitan dengan pelanggaran pidana, karena terbuktinya di persidangan 2 (dua) orang yang menjadi tim terlibat dalam tindak pidana korupsi. Kedua, permasalahan yang berkaitan dengan ketidakpatuhan dalam mengikuti proses atau mekanisme perusahaan dalam melakukan perubahan bentuk.

Berkaitan dengan permasalahan kedua, terdapat dua isu hukum pertamaadalah, adanya 2 (dua) PD. BPR NTB $^{34}$ dari 8 (delapan) PD. BPR NTB yang tidak menyetujui proses perubahan setelah ditetapkannya Perda perubahan yaitu PerdaNomor 10 Tahun 2016 tentang Penggabungan dan Perubahan Bentuk Badan Hukum Perusahaan Daerah Bank Perkreditan Rakyat Nusa Tenggara Barat menjadi Perseroan Terbatas Bank Perkreditan Rakyat $₫$ Nusa Tenggara Barat.

Ketidaksetujuan ini menimbulkan pertanyaan berkaitan dengan kepatuhan terhadap peraturan perundang-undangan yang berkaitan dengan prosedur dan mekanisme perubahan, sebab ternyata setelah Perda ditetapkan dua daerah tidak menyetujui perubahan. Ketidaksetujuan ini menjadi permasalahan secara hukum, karena mekanisme perubahan tidak diselesaikan secara hukum, yaitu persetujuan dari perusahaan atau PD. BPR NTB untuk melakukan perubahan.

Jika mencermati ketentuan yang ada dalam peraturan yang mengatur tentang Perusahaan Daerah (PD), maka keputusan terhadap perubahan bentuk haruslah diputuskan melalui Rapat Pemegang Saham. Ketentuan tentang keharusan diputuskan dalam Rapat

\footnotetext{
${ }^{33}$ Peraturan Pemerintah Nomor 54 Tahun 2017 Tentang Badan Usaha Milik Daerah (Lembaran Negara Republik Indonesia Tahun 2017 Nomor 305, Tambahan Lembaran Negara Republik Indonesia Nomor 6173)

${ }^{34} \mathrm{https}$ ///radarlombok.co.id/gubernur-turun-tangan-tuntaskan-masalah-pt-bpr.html, https://kicknews.today/2017/04/19/kisruh-bpr-ntb-benarkah-ada-titipan-oknum-pejabat/
} 
Pemegang Saham memang tidak diatur dalam Undang-Undang Nomor 5 Tahun 1962 tentang Perusahaan Daerah maupun dalam Undang-Undang Nomor 23 Tahun 2014 tentang Pemerintahan Daerah sebagaimana telah diubah beberapa kali terakhir dengan Undang-Undang Nomor 9 Tahun 2015 tentang Perubahan Kedua Atas Undang-Undang Nomor 23 Tahun 2014 tentang Pemerintahan Daerah. Tetapi karena perubahan ini adalah sesuatu yang penting berkaitan dengan keberadaan perusahaan dan bentuk dari perusahaan, maka seharusnya diputuskan dalam Rapat Pemegang Saham.

Ketidaksetujuan yang terungkap setelah adanya ketetapan Perda menunjukkan bahwa terdapat mekanisme atau prosedur dalam perubahan bentuk tersebut yang tidak dipatuhi, padahal seharusnya mekanisme perusahaan harus diselesaikan terlebih dahulu baru ditetapkan oleh Perda sebagai legitimasi terhadap keputusan perubahan bentuk suatu badan usaha milik daerah.

Jika Perda tentang perubahan telah ditetapkan tetapi mekanisme perusahaan tidak dilakukan secara hukum, maka dapat dikatakan bahwa perubahan bentuk tersebut melanggar hukum, dan pelanggaran itu masuk dalam kategori cacat prosedur. Sehingga untuk memperbaikinya maka yang harus dikoreksi adalah kesalahan yang terdapat dalam prosedur, bukan pada substansi Perda karena kesalahan bukan pada materi Perda.

Kedua, berkaitan dengan kesesuaian dengan bentuk Badan Usaha Milik Daerah (BUMD). Berdasarkan Undang-Undang Nomor 23 Tahun 2014 tentang Pemerintahan Daerah, bahwa bentuk BUMD ditentukan 2 (dua) bentuk yaitu perusahaan umum Daerah dan perusahaan perseroan Daerah.

Dari ketentuan di atas, maka PD. BPR NTB harus sudah menyesuaikan diri dengan bentuk yang ada dalam ketentuan yang ada dalam Undang-Undang Nomor 23 Tahun 2014, yaitu merubah dalam bentuk perusahaan umum daerah atau perusahaan perseroan daerah, dan bukan memilih bentuk Perseroan terbatas. Penyesuaian dengan bentuk yang ada dalam Undang-Undang berakhir pada bulan Oktober 2017, sebab transisi yang diberikan selama 3 (tiga) tahun oleh Undang-Undang, seperti yang diatur dalam Pasal 402 ayat (2) Undang-Undang Nomor 23 Tahun 2014 yang menyebutkan "BUMD yang telah ada sebelum Undang-Undang ini berlaku, wajib menyesuaikan dengan ketentuan dalam Undang-Undang ini dalam jangka waktu paling lama 3 (tiga) tahun terhitung sejak Undang-Undang ini diundangkan".

Di samping itu juga bahwa Undang-Undang yang menjadi dasar bagi Perusahaan Daerah telah dicabut dan dinyatakan tidak berlaku, seperti yang diatur dalam Pasal 405 Undang-Undang Nomor 23 Tahun 2014, yang menyebutkan "Pada saat Undang-Undang ini mulai berlaku: Undang-Undang Nomor 5 Tahun 1962 tentang Perusahaan Daerah (Lembaran Negara Republik Indonesia Tahun 1962 Nomor 10, Tambahan Lembaran Negara Republik Indonesia Nomor 2387) dicabut dan dinyatakan tidak berlaku. 


\section{SIMPULAN}

Kewenangan DPR dalam pengisian pejabat negara dapat berbentuk pengajuan, pemilihan, pemberian persetujuan, pertimbangan dan konsultasi. Kondisi tersebut menunjukkan peralihan kekuasaan yang semakin memperkuat kekuasaan DPR khususnya setelah amandemen UUD NRI Tahun 1945. Penguatan kekuasaan DPR tersebut dalam praktiknya tidak dibarengi dengan proses yang partisipatif dan transparan bahkan terjadi proses politicking serta kasus penyuapan, sehingga mendorong berbagai elemen untuk mengevaluasi berbagai macam bentuk keterlibatan DPR dalam pengisian pejabat negara. Selain itu keterlibatan DPRD dalam kebijakan atau proses yang ada pada perusahaan pemerintah seperti BUMD sering berkonsekuensi pada pelanggaran hukum, hal tersebut dikarenakan perbedaan kedudukan atau legal standing dari masing-masing otoritas institusi. DPRD adalah lembaga politik yang cenderung transaksional sedangkan BUMD adalah institusi bisnis yang berorientasi profit dalam peningkatan pendapatan daerah.

Perbedaan fungsi dan tujuan dari kedua lembaga ini mengakibatkan disparitas dalam kebijakan dan proses yang ada di BUMD, keterlibatan DPRD sering dimaknai sebagai bentuk intervensi yang mengganggu tatanan BUMD, dan sering menimbulkan permasalahan hukum, karena tidak bisa dihindari bahwa DPRD adalah lembaga politik.

Oleh karena itu keikutsertaan pihak lain yang memiliki integritas dan profesionalitas, seperti keterlibatan panitia seleksi dalam pemilihan pimpinan BUMD, dapat menjadi alternatif guna mempertahankan sisi positif kewenangan pengawasan DPRD, dan untuk mengurangi dampak negatif yang sering kali muncul.

Dengan demikian kewenangan DPRD dalam pengisian pejabat BUMD dapat dibenarkan sepanjang sesuai dengan kaidah yang diatur dalam peraturan peundang-undangan dengan menerapkan model yang partisipatif dan transparan, sehingga tetap terwujud checks and balances dalam pelaksanaan pemerintahan.

\section{DAFTAR PUSTAKA}

\section{Buku}

Bryan A. Garner (ed.) (1999), Black's Law Dictionary Seventh Edition, (St. Paul Minn: West Publishing Co.,.

Cristian Wibisono, (1995) Merger dan Akuisisi di Indonesia, Seminar Merger dan Akuisisi, Jakart,.

Pringle, J. J. , and Harris, R. S, (1987), Essentials of Managerial Finance, second IllinoisLondon.

I Gde Panca Astawa, (2008) Problematika Hukum Otonomi Daerah di Indonesia, Alumni, Bandung,

J Kaloh. (2002), Mencari Bentuk Otonomi Daerah Suatu Solusi Dalam Menjawab 
Kebutuhan Lokal dan Tantangan Global, Rineka Cipta, Jakarta.

\section{Jurnal}

Ikhwansyah, I., Chandrawulan, A. A., \& Amalia, P. (2018). Optimalisasi Peran Badan Usaha Milik Negara (BUMN) pada Era Masyarakat Ekonomi Asean (MEA). Jurnal Media Hukum, 25(2), 150-161.

Muryanto, Y. T. (2014). Model Pengelolaan Badan Usaha Milik Daerah (BUMD) Dalam Rangka Mewujudkan Good Corporate Governance. Yustisia Jurnal Hukum, 3(1).

Rajab, A. (2018). PERAN PENTING BADAN KEAHLIAN DPR RI DALAM SISTEM HUKUM PEMBENTUKAN PERATURAN PERUNDANG-UNDANGAN YANG MENDUKUNG TERWUJUDNYA KEADILAN UNTUK KEDAMAIAN. Jurnal Legislasi Indonesia, 14(2), 233243.

Sunardi, Fungsi Pengawasan DPR terhadap Pemerintah dalam Mewujudkan Good Governance dan Clean Government ditinjau dari Perspektif Politik Hukum, Jurnal Meta Yuridis Volume 1 No.2 Tahun2018.

Sri Widiyastuti, Politik Hukum Badan Usaha Milik Daerah (BUMD) dalam Kegiatan Bisnis untuk Mewujudkan Kesejahteraan Sosial, Jurnal Law and Justice, Vol. 4 No. 1 April, 2019.

\section{Peraturan Perundang-undangan}

UUD NRI Tahun 1945

Undang-Undang Nomor 23 Tahun 1999 Tentang Bank Indonesia (LNRI Tahun 1999 Nomor 66, TLNRI No 3843).

Undang-Undang Nomor 39 Tahun 1999 TentangispepitHak Asasi Manusia (LNRI Tahun 1999 Nomor 165, TLNRI No 3886).

Undang-Undang Nomor 2 Tahun 2002 Tentang Kepolisian Negara Republik Indonesia(LNRI Tahun 2002 Nomor 2, TLNRI No 4168).

Undang-Undang Nomor 30 Tahun 2002 Pidana Korupsi (LNRI Tahun 2002 Nomor 137, TLNRI No 4250).

Undang-Undang Nomor 19 tahun 2003 tentang Badan Usaha Milik Negara (Lembaran Negara Republik Indonesia Tahun 2003 Nomor 70, Tambahan Lembaran Negara Republik Indonesia Nomor 4297)

Undang-Undang Nomor 34 Tahun 2004 Tentang Tentara Nasional Indonesia (LNRI Tahun 2004 Nomor 127, TLNRI Nomor 4439).

Undang-Undang Nomor 40 Tahun 2007 tentang Perseroan Terbatas (Lembaran Negara Republik Indonesia Tahun 2007 Nomor 106, Tambahan Lembaran Negara Republik Indonesia Nomor 4756).

Undang-Undang Nomor 12 Tahun 2011 tentang Pembentukan Peraturan PerundangUndangan (Lembaran Negara Republik Indonesia Tahun 2011 Nomor 82, Tambahan Lembaran Negara Republik Indonesia Nomor 5234) sebagaimana telah diubah dengan Undang-Undang Nomor 15 Tahun 2019 tentang Perubahan atas Undang-Undang Nomor 12 Tahun 2011 tentang Pembentukan Peraturan Perundang-Undangan (Lembaran Negara Republik Indonesia Tahun 2019 Nomor 183, Tambahan Lembaran Negara Republik Indonesia Nomor 6398). 
Undang-Undang Nomor 21 Tahun 2011 Tentang Otoritas Jasa Keuangan (LNRI Tahun 2011 Nomor 111, TLNRI No 5253).

Undang-Undang Nomor 23 Tahun 2014 tentang Pemerintahan Daerah (Lembaran Negara Republik Indonesia Tahun 2014 Nomor 244, Tambahan Lembaran Negara Republik Indonesia Nomor 5587) sebagaimana telah beberapa kali di ubah terakhir dengan Undang-Undang Nomor 9 Tahun 2015 tentang Perubahan Kedua Atas Undang-Undang Nomor 23 Tahun 2014 tentang Pemerintahan Daerah (Lembaran Negara Republik Indonesia Tahun 2015 Nomor 58, Tambahan Lembaran Negara Republik Indonesia Nomor 5679).

Undang-Undang Nomor 7 Tahun 2017 Tentang Pemilihan Umum (LNRI Tahun 2017 Nomor 182, TLNRI No 6109).

Peraturan Presiden Nomor 87 Tahun 2014 tentang Peraturan Pelaksanaan Undang-Undang Nomor 12 Tahun 2011 tentang Pembentukan Peraturan Perundang- Undangan (Lembaran Negara Republik Indonesia Tahun 2014 Nomor 199).

Peraturan Menteri Dalam Negeri Nomor 80 Tahun 2015 tentang Pembentukan Produk Hukum Daerah (Berita Negara Republik Indonesia Tahun 2015 Nomor 2036).

Peraturan Pemerintah Nomor 54 Tahun 2017 Tentang Badan Usaha Milik Daerah (Lembaran Negara Republik Indonesia Tahun 2017 Nomor 305, Tambahan Lembaran Negara Republik Indonesia Nomor 6173).

\section{Internet}

http://nasional.sindonews.com/berita/788395/dpr-memang-kebablasan, diakses Rabu, 19 Agustus 2020

https://www.larasonline.com/berita/MK-Tolak-Permintaan-Pelibatan-DPR-Dalam-Aksi-Korporasi-Penggabungan-BUMN, diakses pada tanggal 27 Agustus 2020

https://kolom.tempo.co/read/1000336/bahaya-dpr-memilih-direksi-bumn, diakses pada tanggal 10 Agustus 2020

https://www.hukumonline.com/berita/baca/lt5c1230587092e/menyoal-superioritasdpr-dalam-revisi-uu-bumn/ diakses pada tanggal 27 Agustus 2020

https://radarlombok.co.id/gubernur-turun-tangan-tuntaskan-masalah-pt-bpr.html, https://kicknews.today/2017/04/19/kisruh-bpr-ntb-benarkah-ada-titipan-oknumpejabat/ 